ANNA MARIA PISKORSKA

Instytut Sztuk Audiowizualnych Uniwersytet Jagielloński w Krakowie

\title{
Poświęcić niepewność - prolegomena do badań nad kinem postsekularnym
}

\begin{abstract}
Piskorska Anna Maria, Poświęcić niepewność - prolegomena do badań nad kinem postsekularnym [Sacrificing uncertainty - prolegomena to the study of post-secular cinema]. "Images" vol. XXX, no. 39. Poznań 2021. Adam Mickiewicz University Press. Pp. 47-66. ISSN 1731-450X. DOI 10.14746/i.2021.39.03.

This article undertakes the issue of defining film phenomena which put forward questions of a primary religious nature (about the meaning of life, source of evil, life after death, the existence of Absolute, etc.) in a way that is independent from major religious traditions. The author posits that describing this phenomenon in the case of European film culture is done best by employing the philosophical thought of postsecularism. Utilizing Mieke Bal's method of cultural analysis, the author takes as an example the term 'sacrifice' to point to the existence of different models by which religious topics are undertaken by the cinema. This leads to a preliminary typology of the phenomenon which differentiates between 'apologetic' and 'critical' films and, furthermore, between films that refer to particular religious traditions and those expressing a postsecular perspective.
\end{abstract}

KEYWORDS: postsecularism, postsecular cinema, postmodernism, cultural analysis, Mieke Bal, religious film, European cinema, Bruno Dumont, Hadewijch, John McDonagh, Calvary, Xavier Beauvois, Of Gods and Men.

Kinematografia europejska XXI wieku dowodnie wskazuje, iż filmowy namysł nad światem wartości religijnych wszedł właśnie w nowy etap. Widać to dobitnie w swobodzie ruchów Mężczyzny (Poza Szatanem, reż. Bruno Dumont, 2011), który uzdrawia, zabija i wskrzesza, przed nikim nie tłumacząc się ze swoich działań ani ze źródeł własnej mocy; w magnetycznym wzroku Justine (Melancholia, reż. Lars von Trier, 2011), jakim wpatruje się w Melancholię - planetę niosącą zagładę Ziemi; w tajemniczym spojrzeniu, które rejestruje intymne życie Anne i Georgesa, a na znak swojej obecności podsyła kolejne kasety wideo (Ukryte, reż. Michael Haneke, 2005); w statycznym czekaniu oka kamery na to, aż w kadrze pojawią się z powrotem Ojciec z Córką (Koń turyński, reż. Bela Tarr, 2011), zyskawszy pewność, że nie mają dokąd uciec przed nadchodzącym końcem świata. Wartości, które uobecniają się w tego typu filmowych przedstawieniach, choć historycznie łączone są ze sferą sacrum, zostały pozbawione swojego pozaświatowego statusu oraz odarte z mocy zmieniania rzeczywistości.

Załamanie się porządku świata strukturyzowanego podług religijnych wartości jest znamienne dla kultury europejskiej i w tym kręgu
Images

vol. XXX/no. 39

Poznań 2021

ISSN 1731-45Ox

\section{Niereligijna odpowiedź na religijne pytania}


zamykać się będą niniejsze rozważania[1]. W odniesieniu do dziejów europejskich kinematografii warto wskazać, iż poczucie aksjologicznej niepewności nie jest zjawiskiem nowym, ponieważ w historii tej sztuki stanowiło od początku istnienia kina twórczą alternatywę względem filmu konfesyjnego. Kontakt z Joanną d’Arc (Męczeństwo Joanny d'Arc, reż. Carl Theodor Dreyer, 1928), proboszczem z Ambricourt (Dziennik wiejskiego proboszcza, reż. Robert Bresson, 1951) czy Andriejem Rublowem (Andriej Rublow, reż. Andriej Tarkowski, 1966) wytrąca widza z konwencjonalnie chrześcijańskiego sposobu oceniania natury zjawisk i ludzkich postaw wobec nich. Z kolei podróż w głąb uniwersum Ingmara Bergmana wyczula na przebłysk tajemnicy istnienia w ramach surowych krajobrazów świata ateistów.

Można by mnożyć przykłady tego typu kinematograficznych działań na religijnych znaczeniach. Film jako forma sztuki ma inherentną zdolność do podważania ustalonego porządku społecznego i kwestionowania panującej ideologii. Obcowanie $\mathrm{z}$ kinem stawiającym religijne pytania rodzi zatem szereg wątpliwości natury interpretacyjnej. Czy przestrzeń pozakadrowa „ewokuje Transcendencję" (jak to sugerują niektórzy badacze[2])? Czy wertykalny ruch kamery w górę ku niebu symbolicznie wskazuje na wymianę spojrzeń z Okiem Opatrzności? A może jest to ironiczny gest demaskujący i wyjaskrawiający nieobecność sfery sacrum w symbolicznym uniwersum projektowanym przez dzieło? Jeśli kino potrafi wzmacniać światopogląd religijny przez swoją sugestywność w łączeniu wizji rzeczywistości z jej ideologicznym uzasadnieniem, to czy na przeciwstawnym biegunie tej samej dyspozycji nie znajduje się zdolność do rozbijania tej zależności, czyli do ukazywania nieprzystawalności tych dwóch wymiarów? Świat filmowy jest zawsze przygodny, zmienny i konkretny - co wynika bezpośrednio $\mathrm{z}$ właściwości filmowego medium. Z kolei świat wartości religijnych ma wymiar ostateczny, niezmienny i abstrakcyjny, ponieważ tylko wówczas może stanowić trwałą podstawę dla religijnej doktryny.

Teologowie z zacięciem filmoznawczym doceniają formę filmową za możliwość wcielania uniwersalnych prawd wiary w zmienną materię filmowego świata. W przeciwieństwie do prac teologicznych, obszar badawczy dla niniejszego wywodu stanowią te filmowe fenomeny, które stawiają pytania natury religijnej w sposób niezależny od systemowej konceptualizacji wypracowanej w ramach dominujących światowych ideologii religijnych. Treść tego artykułu stanowi odpowiedź na wy-

[1] Oczywiście nie znaczy to, że historia krajów przynależnych do innych kręgów kulturowych również nie przeszła procesu sekularyzacji. Niemniej kontekst kulturowy tak waży na efekcie tego procesu, iż konieczne jest prowadzenie odrębnych badań w odniesieniu do każdego kręgu kulturowego, a nawet historii danego regionu. Postsekularyzm, o którym traktuje niniejszy artykuł, wyrasta z kultury europejskiej, i choć można $\mathrm{z}$ powodzeniem prowadzić badania nad postsekularyzmem w Indiach lub Azji dalekowschodniej, wywiedzionych wniosków nie można ze sobą konfrontować inaczej, niż tylko w ramach analizy porównawczej.

[2] Określenie odnosi się wprost do koncepcji „stylu transcendencji” Amédée Ayfre’a, upowszechnionej na gruncie polskiego filmoznawstwa przez Mariolę Marczak - zob. eadem, Poetyka filmu religijnego, Kraków 2000. 
zwanie, jakim jest wypracowanie adekwatnego języka do opisu filmu udzielającego niereligijnej odpowiedzi na źródłowo religijne pytania[3].

Można założyć, iż obszar badań wykreślany przez alternatywne interpretacje problemów o naturze religijnej stanowić będzie najrozleglejsze pole filmoznawczego dorobku obejmującego wzajemne relacje „filmu” i „religii”. Bogaty materiał kinematograficzny realizujący krytyczną perspektywę względem doktryn i instytucji religijnych dobitnie wskazuje na konieczność prowadzenia tego typu badań. Wbrew temu założeniu problematyka niniejszego artykułu okazuje się niedostatecznie rozpoznana przez filmoznawców zainteresowanych relacjami religii i filmu. Przyczyn tego stanu rzeczy można upatrywać w sekularyzmie, z którego wyrasta dyskurs filmoznawczy[4]. Za sprawą ideologii sekularnej, wprowadzanej na grunt akademicki od Oświecenia, definicja religii (miała ona na celu jej dyskredytację jako podejścia opozycyjnego do naukowego) wskazywała na jej irracjonalność i nieweryfikowalność, a także ideologiczny i instytucjonalny wpływ Kościoła.

W ten sposób przez dekady jedynymi badaczami pola wzajemnych wpływów filmu i religii byli teolodzy. W swoich pracach doprowadzali oni do swego rodzaju pojęciowych nadużyć, uniwersalizując perspektywę badawczą reprezentowanej przez nich dziedziny - wiara oznaczała wiarę w Boga, wymiar transcendentny sugestię Bożej obecności itd. Zainteresowanie teologów filmem wiązało się z dostrzeżeniem $\mathrm{w}$ tym medium szansy na powrót tematów religijnych do przestrzeni publicznej (z której religia była konsekwentnie rugowana). Przy czym wielu badaczy traktowało film jedynie jako niedoskonałe medium dla wyrażania treści religijnych, a zatem film i religia w oczach teologów nie miały równorzędnej rangi[5].

Obecna sytuacja wskazuje na zmianę statusu religii w przestrzeni publicznej oraz w świecie nauki. Przypuszczam, iż ponowny namysł nad źródłowo religijnymi pytaniami stał się możliwy za sprawą postępującego od końca XIX wieku rozwoju religioznawstwa - dziedziny, która wypracowała metajęzyk do opisu fenomenu religii oraz ludzkiej religijności i w ten sposób przeniosła religijny dyskurs na inny poziom. $\mathrm{Z}$ dorobku religioznawstwa korzystają z powodzeniem zarówno filozofowie, jak i socjologowie, antropolodzy czy wreszcie badacze sztuki. Poprzez wprowadzenie odmiennych od konfesyjnego sposobów opisu zjawisk religijnych filmoznawstwo zyskało sposobność do poszerzenia

\section{Perspektywa} sekularna
[3] „Pytania źródłowo religijne” (lub skrótowo: pytania religijne) to pytania, od których wzięły swój początek wszystkie systemowe religie. Obejmują one trzy wymiary - egzystencjalny, etyczny i eschatologiczny - i dotyczą kwestii takich jak sens życia, przyczyny cierpienia, źródło zła, natura dobra, życie po śmierci oraz nadrzędne zasady bądź byty rządzące światem.
[4] Zob. J. Caruana, M. Cauchi, What is postsecular cinema? An introduction, [w:] Immanent Frames: Postsecular Cinema between Malick and von Trier, red. J. Caruana, M. Cauchi, New York 2018, epub. Zob. także: S. Cooper, The Soul of Film Theory, New York 2013, s. 1-4.

[5] Zob. przykładowe ujęcie w: C. Deacy, G.W. Ortiz, Theology and Film: Challenging the Sacred/Secular Divide, Malden 2008, epub. 
i rozwinięcia obszaru badań wzajemnych wpływów filmu i religii, co zaowocowało licznymi publikacjami, szczególnie na przestrzeni ostatnich dwóch dekad[6]. Zagłębiając się w ich lekturę, można stwierdzić, że obecnie teologiczna perspektywa jest równoważona przez filozoficzną i religioznawczą, co odpowiada zresztą naturze religijnych pytań. Jeśli zaś przyjrzymy się podejmowanym dotychczas próbom klasyfikacji kwestii kluczowej dla naszych rozważań - czyli niereligijnych odpowiedzi na religijne pytania - okaże się, iż uznane przez badaczy za najadekwatniejsze do zrozumienia tej kwestii filozoficzno-religioznawcze pojęcie-klucz (choć używane również jako wytrych) to „postsekularyzm”.

Kino postsekularne?

\section{Postsekularyzm - pojęciowy porost}

Postsekularyzm jako twór językowy wydaje się, po pierwsze, niesamoistny, po drugie zaś - niekonkretny. Słowotwórcze użycie przedrostka "post-” podlega dalszym interpretacjom, o czym pisał Jean-François Lyotard w odniesieniu do postmodernizmu[7]. Przedrostek „post-” wskazuje na diachroniczne następstwo kolejnego okresu, wyraźne odcięcie się od poprzedniej epoki, ale nie precyzuje charakteru i konsekwencji owego odcięcia.

Próba zrozumienia, czym jest postsekularyzm, przysparza trudności: po pierwsze dlatego, iż sam sekularyzm jest zjawiskiem złożonym i niełatwym do zdefiniowania. Nie jest to bowiem pojedyncze zdarzenie, lecz proces, który rozpoczął się w momencie ustalenia postulatów oświeceniowych (kultu rozumu, wiary w racjonalność i proklamowania ideału świeckiego człowieka[8]), które z większym lub mniejszym powodzeniem próbowano wcielać w struktury społeczno-polityczno-kulturowe przez ostatnie trzy stulecia. Ocena, czy ów projekt się powiódł, stanowi do dziś przestrzeń sporu badaczy. W radykalnym sensie zapewne nie, gdyż perspektywa religijna nigdy nie została w pełni wyparta z przestrzeni publicznej, a chrześcijańska etyka znajduje swoje refleksy w konstytucjach wielu europejskich państw. Z drugiej strony konsekwentnie ograniczane wpływy myślenia religijnego doprowadziły do kulminacji w latach sześćdziesiątych XX wieku, kiedy to wartości wywiedzione $\mathrm{z}$ chrześcijańskiej teologii przestały mieć realne znaczenie w ramach domeny tak zwanej kultury zachodniej[9].

Termin „postsekularyzm” zaczął być używany w późnych latach dziewięćdziesiątych za sprawą książki Phillipa Blonda Post-secular Philosophy, w której autor wskazywał poprzez wprowadzenie tego po-

[6] Reprezentatywnymi przykładami są: The Religion and Film Reader, red. J. Mitchell, S.B. Plate, New York 2007; P.V.M. Flesher, R. Torry, Film \& Religion: An Introduction, Nashville 2007, The Routledge Companion to Religion and Film, red. J. Lyden, London 2009; The Continuum Companion to Religion and Film, red. W. Blizek, London, New York 2009.
[7] Zob. J-F. Lyotard, Nota o sensach przedrostka post-, [w:] idem, Postmodernizm dla dzieci. Korespondencja 1982-1985, przeł. J. Migasiński, Warszawa 1998, s. 101-109.

[8] A. Kyrlezhev, The postsecular age: Religion and culture today, „Religion, State and Society” 2008, nr 1(36), s. 23.

[9] Zob. H. McLeod, The Religious Crisis of the 196os, New York 2007, s. 124-140. 
jęcia na kolejną zmianę kulturową przywracającą wartość pytaniom natury religijnej w przestrzeni kultury[10]. W ciągu kolejnych lat termin ów został zaadaptowany przez przedstawicieli bardzo różnych poglądów: dla teologów oznaczał powrót do założeń chrześcijaństwa, dla socjologów - pojawienie się nowych ruchów religijnych, zaś dla ateistycznych filozofów - budowanie świadomości etyczno-duchowej w opozycji do wielkich systemów religijnych[11].

Jedyne, co zdaje się łączyć sprzeczne interpretacje postsekularyzmu, to ostrze krytyki wymierzone każdorazowo w sekularyzm jako ideologię, która została zdyskredytowana, ponieważ nie zdołała zapewnić wiarygodnego uzasadnienia naszego istnienia. Ponadto większość pozostaje zgodna co do konieczności poszerzenia definicji religii, którą myśl sekularna celowo sprowadziła wyłącznie do doktrynalnej i instytucjonalnej formy. Poszerzona definicja powinna uwzględnić religię jako między innymi „strukturę kulturową”, „organizację społeczną”, a także jej psychologiczny wymiar w ramach przejawów ludzkiej religijności[12].

Badaczy postsekularyzmu polaryzuje komplementarne do powyższego twierdzenie, iż poddaje on analogicznej krytyce również ideologie religijne $\mathrm{w}$ ich systemowych realizacjach. Polaryzacja stanowisk została rozpięta pomiędzy dwa krańce: na jednym znajduje się postulat konieczności ponownego docenienia religii (uznania jej niezastąpioności, ponieważ żadna inna ideologia nie odpowiada wprost na pytania natury religijnej) [13], zaś na drugim - bezkompromisowa dekonstrukcja religijnych schematów, a zarazem wskazanie na dramat sekularysty, który, pozbawiony pewności naukowej, nie potrafi już nadać wartości światu ani znaleźć sensownego uzasadnienia dla własnej egzystencji.

Postsekularyzm, który ukazuje ten stan zawodu w pełni jego tragiczności, może stanowić unikatowe studium klęski sekularyzmu. Niemniej ten biegun myślenia postsekularnego również postawę religijną ukazuje w permanentnym stanie kryzysu. Właśnie dlatego, iż konsekwentnie korzysta z poetyki wyczerpania i nie projektuje nadziei na zmianę krytycznego stanu, umożliwia dotarcie do dotychczas nieartykułowanego wniosku, który głosi, iż kryzys religijny, choć nie wyraża się w języku symboli religijnych, wciąż stanowi pewną (krańcową) realizację życia religijnego[14]. Dla niniejszych rozważań taka

[10] Zob. Post-secular Philosophy. Between philosophy and theology, red. P. Blond, New York 1998, s. 1-33. [11] W XXI wieku filozofowie po latach agnostycyzmu lub ateizmu zaczynają się angażować w religijne idee. Pojęcie postsekularyzmu zyskuje na popularności wśród reprezentantów różnych filozoficznych szkół i stanowisk, do których zaliczam między innymi Jacques'a Derridę, Julię Kristevę, Jürgena Habermasa, Jeana-Luca Nancy'ego, czy też Charlesa Taylora, co prowadzi do pogłębienia pluralizmu definicyjnego (spowodowanego samą interdyscyplinarnością tego pojęcia).
[12] The Post-Secular in Question: religion in contemporary society, red. P.S. Gorski, D. Kyuman Kim, J. Torpey, New York 2012, s. 4.

[13] Za taką definicją postsekularyzmu opowiada się Phillip Blond, a także Charles Taylor i Michel de Certeau. Przy czym czynione przez każdego z filozofów diagnozy obecnego stanu świata skutkują reinterpretacją i re-hierarchizacją wartości religijnych wywiedzionych przede wszystkim z tradycji chrześcijańskich.

[14] Tego typu poglądy charakteryzują postawę postsekularnych postmodernistów, w szczególności Jacques’a Derridy. 
perspektywa jest tym bardziej znacząca, iż w jej świetle postsekularyzm zyskuje sposobność, by wypracować formy alternatywnych, czyli niekonwencjonalnych i niereligijnych odpowiedzi na religijne pytania.

\section{Postsekularyzm na gruncie kina postmodernistycznego}

Powyższa interpretacja skłania do myślenia o postsekularyzmie jako spadkobiercy religijnej wrażliwości postmodernistycznej. Podług postmodernistycznego sposobu percepcji religii oraz religijności we współczesnym świecie dopuszcza się wszelkie ich przejawy, w pełnej dowolności zakresów i znaczeń. Postmodernizm, który zanegował prawdziwość konstruktów ideologicznych jako przejawów esencjalizmu (w przypadku systemów religijnych dekonstrukcji uległy: ontoteologia, pewność epistemologiczna i trwałe zasady etyczne), sprowadził wszelką aktywność religijną do różnych form religijnych dyskursów.

Postsekularyzm, wyrosły na tymże filozoficznym podłożu, uznaje różnorodność, synkretyzm i erozję religijnych pojęć. W odróżnieniu od sekularyzmu nie neguje obecności tradycji religijnych w przestrzeni społecznej, lecz odmawia im prawa do dominacji i znaczącego wpływu na określanie ponowoczesnej kultury. W konsekwencji tak obranej strategii dochodzi do rewolucji: zniesienia fundamentalnego podziału na religijne i świeckie. W obliczu tak radykalnej zmiany w myśleniu obie tradycje - religijna i sekularna - uznają postsekularyzm za wroga, a stając z nim w szranki, po raz pierwszy znajdują się po tej samej stronie barykady. Postsekularyzm odpowiada na ten atak przewrotnie jako twór wyrosły na zgliszczach postmodernistycznej dekonstrukcji uwzględnia poglądy obydwu stanowisk, niemniej tylko po to, by każde $\mathrm{z}$ nich rozpuścić w morzu relatywizmu[15].

Przeciwnie do fenomenologicznego opisu rzeczywistości postsekularyzm, który wyzbył się złudzeń o epistemologicznej pewności, postrzega świat jako tajemnicę, do której trzeba podejść niczym do spotkania twarzą w twarz z drugim człowiekiem w atmosferze otwartości - także na to, że obraz, jaki się w tym procesie wyłoni, będzie diametralnie różny od posiadanych wyobrażeń. Ta idea spotkania znajduje odzwierciedlenie w procesie zaangażowania w świat filmowy, ponieważ sytuacja odbioru dzieła filmowego składa się z dwóch komplementarnych poziomów: poznawczego (intelektualnego) i emocjonalnego.

Jak już wspomniałam, bogaty materiał kinematograficzny, który podważa perspektywę religijną, a zarazem utrzymuje w mocy ważkość religijnych pytań, domaga się opisu na gruncie filmoznawstwa. Propozycją nazwania tego typu twórczości jest „kino postsekularne”. Pojęcie to wprowadzili do dyskursu inicjatorzy dwóch monografii: Religion in Contemporary European Cinema: the Postsecular Constellation[16] oraz Immanent Frames: Postsecular Cinema between Malick and von Trier [17].

[15] A. Kyrlezhev, op.cit., s. 26.

[16] C. Ungureanu, Final remarks what is the use of postsecularism? [w:] Religion in Contemporary
European Cinema: the Postsecular Constellation, red.

C. Bradatan, C. Ungureanu, London 2014, s. 199-219.

[17] J. Caruana, M. Cauchi, op.cit. 
Mimo iż autorzy tych tomów uczynili z pojęcia "kino postsekularne” klucz do zrozumienia analizowanych zjawisk filmowych, po lekturze ich książek wciąż pozostaje ono nieprecyzyjne i niejasne. W efekcie mówi się raczej o „konstelacji postsekularnej”, a nie o autonomicznym pojęciu[18].

Niniejszy artykuł powstał w zgodzie $\mathrm{z}$ nadziejami redaktorów obu książek, by kolejni czytelnicy-badacze poczynili dalsze rozpoznanie typologiczne i doprecyzowali metodologiczny potencjał postsekularyzmu[19]. Celem niniejszej pracy jest funkcjonalizacja definicji postsekularyzmu i aplikacja tego pojęcia do analiz bieżących przemian w ramach kultury filmowej, które nie zostały dotychczas w ten sposób opisane ze względu na brak adekwatnych pojęć.

Interdyscyplinarny charakter prowadzonej analizy wymaga dobrania dla niej adekwatnego metodologicznego ugruntowania. Metoda analizy kulturowej autorstwa Mieke Bal proklamuje porzucenie myślenia dziedzinowego (terytorialnego) na rzecz pojęciowego, a zatem proponuje prowadzenie badań w oparciu o pojęcia, a nie „domknięte” teorie, których język pozostaje nieadekwatny do analizy sztuki[20]. Inaczej rzecz się ma w przypadku samych pojęć, które wywodzą się z konkretnych dyskursów (w przypadku problematyki niniejszej pracy z dyskursu filozoficznego i religioznawczego), lecz mają charakter transdyscyplinarny - można je zatem z powodzeniem aplikować do teorii filmu pod warunkiem, że zostaną uwzględnione różnice semantyczne spowodowane nowym kontekstem.

Opis na poziomie pojęć będzie możliwie najściślej „przylegał” do dzieła, ponieważ pojęcia są plastyczne, skłonne do przekształceń, a zarazem nasycone treścią teorii, z których się wywodzą. Dotychczasowy zestaw kategorii dostarczany przez dyskurs filmoznawczy nie wystarcza do klasyfikacji dzieł filmowych, które w niereligijny sposób odpowiadają na religijne pytania. By wypracować te kategorie, potrzebny jest proces przeniesienia kluczowych pojęć $\mathrm{z}$ innych gałęzi humanistyki. W dalszej części artykułu wykażę na przykładzie pojęcia „ofiary”, wywiedzionego z dyskursu religioznawczego, w jaki sposób zachodzi ów proces przeniesienia i jakim dalszym modulacjom ulega pojęcie pod wpływem wymowy dzieła filmowego. To analityczne badanie umożliwi opis sposobów kategoryzowania treści filmowych podług wyrażonego w nich stosunku do wartości religijnych. W konsekwencji zaś ułatwi skonstruowanie wstępnej typologii filmów podejmujących pytania natury religijnej oraz naświetli oryginalne cechy filmowego postsekularyzmu.

[18] Każdy z członków zaproszonego do współpracy interdyscyplinarnego grona humanistów definiuje postsekularyzm inaczej, ponieważ czyni to w ramach interpretacji konkretnych egzemplifikacji filmowych. W ten sposób to treść dzieła warunkuje specyfikę rozumienia postsekularyzmu.

\section{Migrujące miniteorie}

[19] Religion in Contemporary European Cinema..., s. i.

[20] Zob. M. Bal, Wędrujące pojęcia w naukach humanistycznych, przeł. M. Bucholc, Warszawa 2012, s. $47-82$. 
Przykład religijnego pojęcia: definicja „ofiary”
Perspektywa apologetyczna Ludzie Boga (2010)
Wyrażone rzeczownikowo pojęcie „ofiary” (bądź czasownikowo jako „akt poświęcenia się/(czegos”") otwiera na wymiar sakralny: akt poświęcenia czegoś bóstwu uświęca ofiarę[21]. Istnieje wiele teorii na temat natury ofiary, w tym taka, że stanowi ona źródło dla religii i podstawę dla wszelkich zachowań religijnych. Z mnogości definicji wybrałam tę, która odznacza się skrupulatnością, a zarazem szerokim semantycznym zakresem:

„Ofiara” (łac. „to, co jest uświęcane”) [...] przenika praktycznie wszystkie religie, ale niezwykle trudno jest dokładnie określić jej znaczenia - być może dlatego, że jest ich tak wiele. „Ofiara/akt poświęcenia” jest wyraźnie czymś więcej niż techniką: obejmuje dramat, rytuał i działanie, przekształcając doczesną rolę tego, co jest poświęcane. Ogólnie rzecz biorąc, nic, co jest poświęcane, nie ma inherentnej wartości ani świętości, zanim nie zostanie wyróżnione; to poświęcenie nadaje mu wartość naddaną. Ofiara/poświęcenie może być rozumiana/e jako pokuta za winę lub grzech; jako przebłaganie gniewnego bóstwa; apotropeicznie (jako odwrócenie kary, katastrofy itp.); jako oczyszczenie; jako wyraz wdzięczności; substytucyjne (ofiarowanie Bogu substytutu tego, co słusznie należy do niego, np. pierworodnego dziecka); komensalicznie (symbiotycznie) - ustanawiając zjednoczenie z Bogiem lub innymi uczestnikami wspólnoty jako zgodne z formułą do ut des („daję, abyś mógł dać”); ofiara w zamian za dar; jako utrzymywanie porządku kosmicznego (zwłaszcza w ofiarach hinduskich); jako świętowanie; jako sposób radzenia sobie z przemocą w społeczności; jako katharsis; jako zastępcza ofiara na poziomie władzy i jej dystrybucji[22].

Przyjąwszy za punkt wyjścia powyższą - religioznawczą - definicję „ofiary”, przeanalizujmy aktywność tego pojęcia w polu znaczeń trzech egzemplifikacji filmowych, dla których akt poświęcenia stanowi zarazem temat, motor napędzający akcję, psychologiczną motywację dla rozwoju bohaterów, jak również dramaturgiczny punkt kulminacyjny, a przede wszystkim: nośnik nadrzędnych sensów.

Francuski film Ludzie Boga w reżyserii Xaviera Beauvois, który miał premierę w 2010 roku, został bardzo dobrze przyjęty: na festiwalu w Cannes wzbudził kilkuminutową owację na stojąco, święcił triumfy i bił rekordy popularności we Francji[23], a także cieszył się powodzeniem za granicą. Kiedy zaś po relatywnie niedługim czasie od daty premiery rozpoczęto dystrybucję filmu na nośniku DVD, kopię opatrzono audiodeskrypcją dla niewidzących i napisami dla niesłyszących - co wskazuje na dbałość o to, by film zyskał możliwie najszersze grono odbiorców. Strategia ta wzbudza skojarzenia z diagnozowanym współcześnie przez teologów zjawiskiem „nowej widoczności religii” [24], czyli powrotem dyskursów religijnych do przestrzeni publicznej, ponieważ
[21] Sacrifice, [w:] Britannica Encyclopedia of World Religions, red. W. Doniger, M. Frassetto, Chicago 2006, s. 957.

[22] Sacrifice, [w:] The Concise Dictionary of World Religions, red. J. Bowker, Oxford - New York 2000, epub; tłumaczenie własne.
[23] <https://www.boxofficemojo.com/release/ rl2036762113/weekend/>, dostęp: 2.04.2021. [24] Tłumaczenie angielskiego pojęcia „new visibility of religion”. Zob. przykładowe ujęcie: P. Weibler, The re-enchantment of the world and the end of modern art, [w:] The New Visibility of Religion: 
Ludzie Boga bezsprzecznie mogą stanowić głos w dyskusji nad rolą religii w zmieniającym się świecie. Film porusza kwestie samotności i wspólnoty, przymusu i wolności, złożonych relacji z ludźmi i momentami niemniej skomplikowanej relacji z Bogiem. Świat wartości, choć wyraźnie zarysowany w tym dziele, został wyrażony subtelnie i nienachalnie, $\mathrm{w}$ atmosferze dialogu, tolerancji i chęci zrozumienia odmiennych perspektyw. W ramach filmowego świata figurę innego stanowi społeczność muzułmanów, z którymi współżyją w Algierii (czyli dawnej francuskiej kolonii, kraju w 98,5\% zdominowanym przez islam) bracia trapiści - zbiorowy główny bohater, tytułowi „Ludzie Boga”[25].

Ukazanie chrześcijańskich praktyk w ramach niechrześcijańskiego otoczenia okazało się skuteczną strategią, ponieważ ułatwiło odbiorcom o odmiennych religijnych poglądach skomunikowanie się z przesłaniem filmu. Wartości chrześcijańskie (odwaga, poczucie odpowiedzialności i troska o wspólne dobro) zostały przedstawione także jako uniwersalne wartości etyczne, które niereligijny widz może uznać za przejaw laickiego humanizmu. W ten sposób powstał niekontrowersyjny przekaz sankcjonujący obecność chrześcijaństwa we współczesnym świecie za pomocą znanych już narracji o misjonarzach-lekarzach i nauczycielach, którzy nikomu nie narzucają swoich poglądów, lecz niosą pomoc lokalnym społecznościom zarówno w wymiarze etyczno-duchowym, jak i w ramach konkretnej pomocy medycznej, czy też zapewnienia dostępu do edukacji.

Na tak zarysowanym tle wyraźnie się odznacza kluczowy temat filmu - studium współczesnego męczeństwa. Poruszająca historia siedmiu mnichów porwanych i zabitych w niewyjaśnionych do końca okolicznościach[26] stawia pytanie o sensowność poświęcenia życia w imię wartości, w które się wierzy. Wymowa filmu, aktualizująca sposób rozumienia kluczowej dla chrześcijaństwa figury ofiary (wszak uosabia ją sam Chrystus), wykracza poza chrześcijański kontekst w tym sensie, iż może być również odczytana na poziomie ogólnej zasady wierności wyznawanym wartościom oraz na poziomie pytania o granice poświęcenia. Specyficznie poprowadzona linia dramaturgiczna sprowadza akcję na drugi plan, oddając pole refleksji, tak iż film nabiera charakteru moralnego traktatu[27].

Studies in Religion and Cultural Hermeneutics, red. M. Hoelzl, G. Ward, New York 2008, s. 117-127.

[25] Oryginalny francuski tytuł brzmi Des hommes et des dieux - co można przetłumaczyć jako „O ludziach i bogach” - i nawiązuje do słów psalmu: „Ja rzekłem jesteście bogami i wszyscy synami najwyższego, lecz wy pomrzecie jak ludzie i jak jeden mąż książęta poupadacie", [w:] Biblia Tysiaclecia Ps 82,6-7, <https:// biblia.deon.pl/rozdzial.php?id=915\#P1>, dostęp: 2.04.2021.

[26] Historia została oparta na autentycznych zdarzeniach z marca 1996 roku. Choć do zabójstwa mnichów przyznała się Algierska Zbrojna Grupa
Islamska (The Armed Islamic Group of Algeria), to dokumentacja przedstawiona przez francuskie służby specjalne sugeruje możliwość, jakoby to armia algierska mogła popełnić błąd podczas próby ratunkowej, <https://cineuropa.org/en/newsdetail/116152/>, dostęp: 2.04.2021.

[27] Konstrukcja dramaturgiczna Ludzi Boga jest bardzo prosta, trzyaktowa, a każda z części filmu zawiera lustrzaną scenę pracy, modlitwy, interakcji z lokalną społecznością, konfrontacji z wojskiem, ingerencji fundamentalistów oraz kończy się podsumowującą sceną rozmowy mnichów przy stole. 
Stąd też kluczową sceną, kulminacją filmu, nie jest akt wtargnięcia oprawców w klasztorne mury, ale poprzedzająca go scena wspólnej wieczerzy w uroczystość Wielkanocy, stanowiąca odpowiedź na powyższe pytanie. W atmosferze wspólnoty i radości ze zmartwychwstania Chrystusa bohaterowie uświadamiają sobie głębsze znaczenie poświęcenia swojego życia Bogu, czego każdy z nich dokonał, na wzór Jezusa, w dniu składania ślubów zakonnych, ale co nabrało radykalnego rysu dopiero w momencie, gdy faktycznie ich życiu zaczęło zagrażać widmo nagłej śmierci[28]. Wzruszenie malujące się na twarzach mnichów, katalizowane poprzez muzykę Piotra Czajkowskiego (Jezioro łabędzie), sugeruje doświadczenie numinotyczne: bohaterowie świadomi słabości człowieka wobec sił zła nakierowują się na Bożą świętość, w niej upatrując szansy na wyzwolenie. Scena ta łączy dwie cechy numinosum: mysterium fascinans z mysterium tremendum, wyzwalając w ten sposób uczucie wzniosłości[29].

Bohaterowie w akcie poświęcenia swojego życia nie dążą do klasycznie rozumianego męczeństwa (które jest w tym przypadku utożsamiane z pychą i pragnieniem sławy), lecz do przekroczenia świeckiej kondycji ludzkiego życia, które - jak wierzą - zostało uświęcone przez narodziny Chrystusa. By Boża świętość narodziła się w nich samych i przebóstwiła ich ludzkie jestestwo, składają w ofierze swoje życie Bogu. Akt poświęcenia nadaje wartość ich życiu - i jest to wartość absolutna, czyli taka, której nie może zniszczyć przemoc, władza ani śmierć. Chrześcijański akt wiary jest jednocześnie aktem poświęcenia, o którym mówił Chrystus („kto chce zachować swoje życie, straci je, a kto straci swe życie z mego powodu, ten je zachowa"[30]) i który sam urzeczywistnił.

Film Ludzie Boga ukazuje świat niejednoznaczny moralnie (znamienne słowa $\mathrm{z}$ listu pożegnalnego Christiana wypowiedziane w swoistym filmowym epilogu brzmią: „żyję niestety wystarczająco długo, by zrozumieć, że jestem współwinny za zło, które zdaje się rządzić światem"[31]), ale który jest możliwy do uporządkowania poprzez abstrahowanie $\mathrm{z}$ niego pewnych wartości i nadanie im nadrzędnego statusu. Poświęcenie, które jest dobrowolne i realizowane na drodze świadomego wyboru, przynosi bohaterom poczucie absolutnej wolności. Ów akt poświęcenia wymierzony jest również w grzech obecny w świecie i zgodnie z przytoczonymi słowami zakonnika o współwinie może zostać zinterpretowany jako akt pokutny.

[28] Role tak zostały rozpisane, by opinie mnichów zebrane razem stanowily spektrum możliwych postaw względem niezawinionego zła, które przychodzi. Ostatecznie zaś, mimo rozbieżności w tych pierwszych reakcjach, wszyscy podejmują zgodną decyzję pozostania w klasztorze, co jest równoznaczne z symbolicznym odnowieniem ślubów zakonnych. W ten sposób wyraźnie zostaje nakreślona właściwa droga postępowania wobec zła w świecie - nie tyle na poziomie konkretnych działań, lecz przede wszystkim na poziomie proklamowanych wartości.

[29] R. Otto, Świętość, przeł. B. Kupis, Warszawa 1999, s. 9-55.

[30] Biblia Tysiaclecia, Łk 9,24, <https://biblia.deon. pl/rozdzial.php?id=324>, dostęp: 2.04 .2021 .

[31] Ludzie Boga (2010, X. Beauvois), 1:54:20-1:54:30. 
W ten sposób projekcję filmu możemy odczytać jako zaproszenie do uczestnictwa w rytuale ofiarnym, w którym filmowi bohaterowie składają siebie w ofierze, by zaświadczyć o istnieniu świata religijnych wartości, zupełnie niezależnego od zdeprawowanej rzeczywistości. W takiej interpretacji przestanie dziwić fakt, że film o jednoznacznie religijnej wymowie zyskał tak wielką popularność w zsekularyzowanej Francji, gdyż dzieło Xaviera Beauvois z 2010 roku daje pośrednią, ale bardzo wyraźną odpowiedź na powszechną wówczas obawę przed rosnącym w siłę państwem islamskim oraz na wtórną marginalizację społeczności muzułmańskiej (najliczniejszej w Europie).

W proponowanej przeze mnie typologii film Ludzie Boga reprezentuje postawę apologetyczną względem ideologii religijnej, w pełni uznając odpowiedź, jakiej udziela dany system religijny (zazwyczaj jednak utożsamiany z postawą religijną jako taką) na religijne pytania. Za charakterystyczną cechę postawy apologetycznej realizowanej na gruncie kina uznaję konstruowanie przesłania filmowego według tego schematu: rzeczywistość ukazywana w permanentnym kryzysie może zostać wyzwolona od niszczącego ją zła jedynie na płaszczyźnie symbolicznej za sprawą odniesienia do idealnego świata wartości religijnych. Wartości te stanowią ramę dla rzeczywistości, ponieważ ją obejmują, lecz również zdolne są do jej przekraczania, co świadczy o ich wszechmocy. W podtekście filmów apologetycznych kryje się głos nawoływania do tego, by brać przykład $\mathrm{z}$ wierzących bohaterów, czyli tak jak oni zaufać pozaświatowej mocy płynącej z wiary w metafizyczny świat znajdujący swoje odzwierciedlenie $\mathrm{w}$ wartościach niematerialnych, ale wciąż możliwych do dostrzeżenia w ramach rzeczywistości.

Alternatywny do apologetycznego stosunek twórców filmowych do kwestii religii określam jako postawę krytyczną. Perspektywa krytyczna może się odnosić do wybranych aspektów religii: instytucjonalnego, ideologicznego, etycznego etc., choć często obejmuje kilka w ramach jednej artystycznej wypowiedzi. „Krytyczności” owej postawy nie należy utożsamiać z krytykanctwem - nie jest to prosty rewers postawy apologetycznej, lecz inny sposób wplatania treści religijnych w strukturę filmową. Podczas gdy w pierwszym podejściu to wartości religijne stanowią odpowiedź na aporie rzeczywistości, drugi typ odwraca tę zależność i to zmieniający się na naszych oczach świat (jego wyzwania, kryzysy i przeobrażenia) weryfikuje sensowność i skuteczność z natury teoretycznych i w dużej mierze już ustalonych wieloletnią tradycją koncepcji religijnych.

Pozostając w ramach pytań natury religijnej, twórca dzieła nie odpowiada na nie zgodnie z religijną wykładnią, lecz wchodzi z nią $\mathrm{w}$ swoisty dialog. Uznaje perspektywę religijną jako stronę w dyskusji i weryfikuje prawdziwość jej twierdzeń w ramach szeregu aktów negocjacyjnych. Cele tego działania mogą być różne, a jednym z popularniejszych jest chęć obnażenia nawykowych sposobów myślenia o religii i wytrącenia widzów ze schematów poznawczych, w których tkwią

Perspektywa krytyczna 
zarówno jej zwolennicy, jak i adwersarze. Filmy apologetyczne najczęściej utożsamiają świat wartości religijnych z konkretnym systemem: judaizmem, chrześcijaństwem, islamem, hinduizmem etc., w czym upodabniają się do myślenia teologicznego. Filmy krytyczne z kolei nakłaniają do stosowania pojęć z zakresu religioznawstwa, ponieważ obiektywizm i metajęzyk ich opisu (cechujące perspektywę religious studies) stanowią adekwatniejszy punkt wyjścia dla treści filmowych, które wykraczają poza konfesyjny punkt widzenia.

Rozległą grupę filmów podejmujących krytyczny namysł nad wartościami religijnymi należy poddać dalszemu podziałowi: do pierwszej grupy klasyfikuję te dzieła, które odnoszą się do konkretnych systemów religijnych (często tylko jednego) i wyłącznie w oparciu o ten kontekst podejmują namysł nad uniwersalnymi kwestiami, na przykład rolą religii we współczesnym świecie bądź skutecznością religijnych odpowiedzi na pytania fundamentalne dla ludzkiego istnienia. Druga grupa to typ odwrotny: charakteryzuje się bowiem brakiem odniesienia do konkretnych systemów religijnych, a jej diagnozy na temat religijnej kondycji świata mają charakter postsekularny.

\section{W granicach systemu religijnego - Kalwaria (2014)}

Pierwszy typ z opisanych powyżej rodzajów kina krytyczno-religijnego jest szeroko reprezentowany we współczesnych kinematografiach. Przy okazji prowadzenia w tym obszarze badań można zaobserwować pewną zależność, że im bardziej dany kraj jest „religijny” (większość obywateli deklaruje przynależność religijną do danego wyznania), tym większe prawdopodobieństwo, że powstający film będzie się ściśle odnosił do własnej tradycji. Przykładem takiej zależności jest choćby kinematografia polska, ponieważ rodzima twórczość filmowa reprezentująca podejście krytyczno-religijne w większości odnosi swoją krytykę do katolicyzmu, jak to ma miejsce w przypadku najnowszych produkcji tego typu: Boże ciało (reż. Jan Komasa, 2019), Kler (reż. Wojciech Smarzowski, 2018), W imię (reż. Małgorzata Szumowska, 2013). Postawa krytyczna nie wskazuje jeszcze na wybór konkretnej problematyki filmu, lecz bezsprzecznie jednym z dominujących współcześnie tematów (co widać choćby na wyżej wymienionych przykładach) jest krytyka instytucji religijnych jako środowiska zakłamanego, skorumpowanego i zdemoralizowanego, co zostaje skonfrontowane z rzeczywistym bądź sugerowanym przejawem autentycznych (tu: chrześcijańskich) wartości.

Temat poświęcenia, również obecny w polskim kinie (choć przede wszystkim $\mathrm{w}$ typie apologetycznym - w ramach rozbudowanej linii „kina hagiograficznego"[32]), znajduje swoją wyrazistą reprezentację w filmie Kalwaria irlandzkiej produkcji w reżyserii Johna Michaela McDonagha. Irlandia przez wieki stanowiła bastion katolicyzmu. Ten

[32] Mam tu na myśli szereg filmów biograficznych, np. o Karolu Wojtyle, Stefanie Wyszyńskim czy Jerzym Popiełuszce. 
stan rzeczy uległ zmianie dopiero w ostatnim półwieczu, kiedy to postępująca sekularyzacja i wzrost gospodarczego dobrobytu kraju wpłynęły na zmiany mentalne irlandzkiego społeczeństwa. Dalsze ochłodzenie nastrojów społecznych - aż po jawną agresję w stosunku do instytucji religijnych - nastąpiło za sprawą licznych publicznych oskarżeń Kościoła katolickiego o pedofilię[33]. Film porusza ów problem wprost: parafianin postanawia zabić swojego proboszcza (ojca Jamesa), by w ten sposób się zemścić za dawne krzywdy (przemoc seksualną) wyrządzone mu przez innego (już nieżyjącego) kapłana. Skryty za kratkami konfesjonału anonimowy mężczyzna grozi niewinnemu księdzu - ale czy ksiądz jest faktycznie niewinny? Na poziomie indywidualnym sprawa zdaje się oczywista, ponieważ ojciec James nie dokonał w swym życiu zbrodni, za którą ma odpokutować. Niemniej jako reprezentant organizacji kościelnej zostaje oskarżony o to, iż nie wziął wystarczającej odpowiedzialności za przenikający ją grzech. I z tego powodu ginie w końcowej sekwencji filmu.

Ostatecznie bohater decyduje się przyjąć na siebie śmiertelną kulę od mężczyzny-ofiary (który poprzez dokonane morderstwo staje się też katem). Akt poświęcenia, choć ewidentny, jest zarazem niejednoznaczny i kontrowersyjny. Odnosząc się do przytoczonej uprzednio definicji poświęcenia, możemy zobaczyć, że w analizowanym przypadku pojęcie to w sposób wyrazisty nabiera rysu pokutnego: wynika z poczucia winy (obecności grzechu) i ma na celu zadośćuczynienie. Poprzez analizę tej filmowej egzemplifikacji zostaje podkreślony inny od dotychczas omówionego (na przykładzie Ludzi Boga) aspekt procesu sakralizacji w akcie poświęcenia: zanim dojdzie bowiem do cudownego przebóstwienia, konieczny jest proces przekroczenia własnej grzesznej kondycji. Kalwaria ukazuje konieczność poniesienia przez kościół ofiary za własne winy. Nieprzepracowywany problem pedofilii rzutuje bowiem na cały Kościół i istnieje wyraźna sugestia filmowa, iż ostatecznie doprowadzi do jego upadku. Jednak ukrywana pedofilia nie jest jedyną przewiną podważającą wiarygodność Kościoła. Korupcja, zgoda na niesprawiedliwości społeczne, cynizm - to kolejne przykłady oskarżeń, jakie wystosowują względem Kościoła jego filmowi parafianie (reprezentujący współczesne irlandzkie społeczeństwo). Pomysł dramaturgiczny Kalwarii zasadza się na konwencji thrillera, a dopełnia go linia fabularna rodem $\mathrm{z}$ kryminału: jako widzowie nie wiemy, kto jest potencjalnym zabójcą protagonisty, dlatego weryfikujemy pod tym kątem każdą z postaci, z którymi kolejno ojciec James wchodzi w interakcję, dochodząc tym sposobem do zaskakującego wniosku, iz niemal każdy z bohaterów jest wrogo nastawiony do Kościoła i ma ku temu swój osobisty powód.

$\mathrm{W}$ tym ponurym obrazie pewien rodzaj nadziei suponuje epilog, w którym dochodzi do konfrontacji i niemego porozumienia

[33] S. Donnelly, T. Inglis, The media and the Catholic Church in Ireland: Reporting clerical child sex abuse,
"Journal of Contemporary Religion" 2010, nr 1(25), s. 1-2. 
między córką księdza (sprzed święceń kapłańskich) i jego oprawcą - niestety, współodczuwanie tej dwójki opiera się prawdopodobnie przede wszystkim na podobnym doświadczeniu psychicznego bólu i cierpienia, których los nie szczędził obojgu. Świat trwałych wartości w Kalwarii można wywieźć co prawda z chrześcijańskiej etyki, lecz został przedstawiony w kontekście świeckim (bez znaczącej roli Bożej obecności) i zasadza się na wspólnocie przeżyć, otwartości na drugiego człowieka oraz wyrozumiałości. Wartości, które zostają tu wyabstrahowane ze świata, przez co stają się nieśmiertelne, to miłość i przebaczenie. W tym sensie ofiara ojca Jamesa nabiera wymiaru apotropeicznego - staje się intencjonalnym odwróceniem nadchodzącej katastrofy. Tytuł Kalwaria to nawiązanie do męki Chrystusa, a zatem wymowne podkreślenie, że to, co aspiruje do sacrum, musi przejść przez sytuację konania, zmagania się. Obietnica zmartwychwstania jest daleka, a w pełni wybrzmiewa pierwsza część prawdy objawionej o zmartwychwstaniu, czyli że „Chrystus prawdziwie umarł”. Wiarę w zmartwychwstanie Kościoła podważa ponadto kontrast między ojcem Jamesem (przynależącym do starego pokolenia) a ojcem Learym, reprezentującym przyszłość Kościoła - młodym, zamkniętym w sobie księdzem, który nie czuje powołania, a Kościół traktuje jak firmę - instytucję, która ma przynosić zyski jak każde inne przedsięwzięcie biznesowe.

W perspektywie postsekularnej - Wierząca (2009)

Przykład drugiego typu kina krytycznie-religijnego stanowi twórczość Brunona Dumonta, współczesnego reżysera-filozofa, którego aspiracją było kreowanie sfery mistycznej w oderwaniu od znaczeń konotowanych przez tradycje religijne[34]. Postsekularny namysł krytyczny różni się od opisanego na przykładzie Kalwarii nie tylko zakresem pojęciowym (pojęcia oderwane od religijnych źródeł), lecz także samym sposobem uprawiania krytyki: obecne w pierwszym typie publicystyka, psychologizacja i silna kontekstualizacja przedstawianej problematyki, w drugim typie oddają pola filozoficznemu dyskursowi, w którym bohaterowie, wydarzenia i świat przedstawiony stają się elementami onto-epistemicznego konstruktu myślowego. Mimo tak wyraźnych filozoficznych podstaw tej postawy twórczej nadrzędna w przypadku sztuki funkcja estetyczna wyraźnie odróżnia film od filozoficznego traktatu. Dzieło filmowe stanowi bowiem źródło estetycznych przeżyć holistycznie odbieranych przez widza zarówno na drodze intelektualnej analizy, jak i poprzez sferę emocji, estetycznego smaku, a także wręcz cieleśnie (o czym traktuje popularna obecnie koncepcja ucieleśnienia w teorii filmu[35]). Bruno Dumont w swoich wizjach filmowych realizuje całe

[34] Opisywana postawa twórcza odnosi się przede wszystkich do pierwszego okresu twórczości Dumonta, czyli czasu od połowy lat 9o. XX wieku do 2011 roku, kiedy miała miejsce premiera filmu Poza szatanem.
[35] Zob. Haptic visuality (embodied spectatorship), [w:] Oxford Dictionary of Film Studies, red. A. Kuhn, G. Westwell, Oxford 2012, epub. 
powyższe spectrum: to reżyser kontrastów, który nie stroni od fizjologicznego języka opisu dla pojęć źródłowo ewokujących sferę sacrum. Poprzez przykład własnej twórczości ukazuje możliwość poszerzania zakresu religijnych pojęć wywiedzionych z tradycyjnych kontekstów i inspiruje badaczy wizualnego postsekularyzmu do tworzenia metafor, takich jak „cielesna mistyka” czy „fizjologia sacrum”.

Postawa twórcza Dumonta stanowi doskonały przykład tropionego $\mathrm{w}$ ramach niniejszej pracy podejścia pojęciowego. Sam reżyser w udzielanych wywiadach (choć głos autora w ponowoczesności stracił na znaczeniu[36]) wyrażał wprost swoją niezgodę na zawłaszczenie przez chrześcijaństwo pojęć, które kategoryzują nasze życie także wtedy, gdy jako agnostycy lub ateiści nie odnosimy ich do tradycyjnie religijnych wykładni i wyobrażeń. Przykład filmu Wierzaca ukazuje, w jaki sposób wyjaskrawiona do ekstremum figura ofiary zupełnie zmienia znaczenie pojęcia poświęcenia w kontekście dotychczasowych religijnych wykładni.

Film Wierząca, który znalazł się we francuskiej, a następnie międzynarodowej dystrybucji w tym samym roku co Ludzie Boga, stanowi niejako drugi biegun tamtej filmowej wypowiedzi. Podczas gdy pierwszy łagodził coraz bardziej napięte relacje chrześcijańsko-muzułmańskie we współczesnej Francji, drugi jedynie może je zaognić. Oba dzieła ukazują bohaterów w stanie najwyższej konieczności, przejętych złem, które widzą w świecie, i zaniepokojonych brakiem na nie Bożej odpowiedzi. Aliści podczas gdy społeczność braci trapistów wzbudza w widzach sympatię, a ich postawa ufności i wierności (pomimo rozterek i strachu) powoduje wzruszenie i podziw, dążenia bohaterki Wierząca - młodej Céline - budzą niechęć i narastający niepokój. Każdy z filmów na swój sposób penetruje granicę poświęcenia, lecz pierwszy odnajduje ją dużo bliżej - jako postawę mieszczącą się w ramach chrześcijańskich zasad (które „są po to, żeby nas chronić”: według słów przeoryszy, bohaterki filmu Dumonta), drugi zaś obrazuje poświęcenie jako działanie totalne, wpierw transgraniczne, by stać się bezgranicznym i w takim wymiarze wybrzmieć jako... niepotrzebny nikomu akt autodestrukcji.

Nie koniec jednak na tym, ponieważ opętana obsesyjnym pragnieniem fizycznego odczucia boskiej intymności Céline, która przybrała imię średniowiecznej mistyczki Hadewijch, w imię Bożej miłości staje się też niebezpieczna. Odnosząc się do poczynionego założenia, iż dzieło Dumonta wyraża postsekularne spojrzenie na źródłowo religijne treści, Céline przeżywa swoją wiarę samotnie (w przeciwieństwie do kolektywizmu wspólnot religijnych) i w poczuciu opuszczenia: w oderwaniu od katolickich zasad (zostaje oddalona $\mathrm{z}$ klasztoru za niesubordynację), w zlekceważeniu przez bliskich, lecz przede wszystkim (ponieważ ten fakt odczuwa najboleśniej) w odrzuceniu przez Boga.

[36] Zob. R. Barthes, Śmierć autora, przeł. M.P. Mar-

kowski, „Teksty Drugie” 1999, nr 1/2, s. 250. 
Dlatego decyduje się na skrajną ascezę i poświęcenie całej swojej siły życiowej na odnalezienie łączności z Chrystusem jako swym oblubieńcem. Ukazana w ten sposób miłość do Boga nabiera fizycznego wymia$\mathrm{ru}$ łącząc duchową sferę sacrum z cielesną sferą profanum - w czym faktycznie upodabnia się do poezji mistyczno-miłosnej flamandzkiej wizjonerki Hadewijch[37]. I choć Céline mówi o swojej wierze słowami niemalże wyjętymi z poematów średniowiecznej mistyczki, wewnętrznie przeżywa swą miłość radykalniej niż Hadewijch, jak w pełni tragiczna bohaterka melodramatu, ponieważ jej ukochany pozostaje wciąż milczący i daleki.

Przeorysza brutalnie określa Céline karykaturą zakonnicy. A jednak w postawie dziewczyny, w jej słowach nieustannego wołania do Niego, bez trudu odnajdujemy postawę radykalnego oddania charakterystyczną dla mistyków. Choć Céline wraca do świata, to jej percepcja wciąż pozostaje ukierunkowana na sacrum - w rzeczywistości pustych ulic, domów i kościołów szuka wskazówek do dalszej drogi. Przypadek sprawia, że poznaje mężczyzn, których wiara jest żywa i nastawiona na radykalne działanie. Wówczas powie:

To Bóg, nasz Bóg doprowadził mnie do was. Jestem gotowa przez wzgląd na moje życie i wiarę działać u boku moich braci i sióstr, którzy $\mathrm{z}$ narażeniem życia walczą w Bogu i w imię Boga, aby mógł on żyć w każdym $\mathrm{z}$ nas. Wierzę $\mathrm{w}$ jego światło, które nas prowadzi, i pragnę działać przez miłość do niego[38].

Dumont nie stroni od ironii - faktycznie bowiem, zgodnie z planami sióstr, które posłały Céline z powrotem do domu, więcej jest w „Zwykłym” świecie (czyli poza klasztornymi murami) okazji, by dowieść swojej miłości do Boga. Céline traktuje tę misję bardzo poważnie - trafiając do grupy terrorystycznej (co nie jest powiedziane wprost, lecz konsekwentnie sugerowane), bierze udział w ataku bombowym na paryskie metro. Wybuch następuje w miejscu wielce symbolicznym - tuż przy Łuku Triumfalnym - i zostaje sfilmowany na tle powiewającej francuskiej flagi. Jednak Dumont wykracza poza polityczne konteksty i - wbrew oburzeniu krytyków - niekoniecznie pragnie wzmacniać społeczne antagonizmy. Wiara muzułmanów stanowi dla Céline przeciwwagę dla pustych kościołów i odległych bliskich, ponieważ jest żywa, stale obecna w ich życiu i skłania do działania. Lecz i ona finalnie, nawet w swej najradykalniejszej ekstremistycznej odsłonie, nie niesie dziewczynie upragnionego spotkania.

Céline cierpi faktyczne męki, a ich źródłem jest bolesny rozdźwięk między naturą boską i naturą ludzką. Próbuje więc przezwyciężyć własną śmiertelność i zarazem szuka człowieczeństwa w Chrystusie - figurze Boga-człowieka. Jednak poprzez złożenie siebie w ofierze doświadcza objawienia, iż żaden akt przebóstwienia nigdy nie nastąpi.

[37] Zob. M.V. Roberts Hadewijch (mid 13th century), [w:] The Encyclopedia of Christian Civilization, red.

G.T. Kurian, Malden 2011, epub.
[38] Hadewijch (2010, B. Dumont), 1:19:25-1:21:45. 
Kiedy rozżalona (i zapewne przerażona konfrontacją z policją i konsekwencjami swoich czynów) postanawia się zabić, ratuje ją mężczyzna, który wyraża Ludzką Obecność. Céline w tym akcie spotkania ma szansę nawrócić się na człowieka, lecz z drugiej strony - jeśli prześledzić losy i poglądy słynnych mistyków - może równie dobrze całe życie tęsknić za tym, który jest nieobecny.

Współczesne badania z obszaru antropologii religii nad relacją religii i europejskich kultur wykazały zasadniczą zamianę ról (określaną jako „duchowa rewolucja”): kultura nie tylko przestała być zależna od perspektywy religijnej, ale wręcz obecnie to ona interpretuje zakres i znaczenie religii w Europie[39]. Postsekularyzm, stanowiący niereligijne podejście do religijnych tematów, oferuje filozoficzne poszerzenie sfery duchowej jako transgranicznej przestrzeni zastępującej dotychczasowy podział na „religijne” i „świeckie”. Trudność polega na tym, iż „duchowość” - szczególnie w ujęciu postmodernistycznym - pozostaje pojęciem wieloznacznym, przez co wymykającym się prostemu opisowi. W odniesieniu do niniejszych rozważań szczególnie inspirująca okazuje się definicja psychologa religii, Pawła M. Sochy: „Duchowość to aktywny proces (lub zintegrowany zespół procesów psychicznych) stanowiący adaptacyjną odpowiedź każdego człowieka na świadomość własnej egzystencjalnej kondycji”[40].

Pytania natury religijnej - stanowiące punkt wyjścia dla mojego artykułu - można określić jako pytania egzystencjalne wyrażone w perspektywie przekraczającej jednostkową ludzką egzystencję. Postsekularyzm w duchu postmodernistycznym utrzymuje w mocy treść owych pytań, lecz bez wiary w systemowe odpowiedzi religii. Miast tego wyraźnie wskazuje na niepopularne stwierdzenie, iż kryzys religii jest także - krańcową, lecz wciąż - formą życia religii, a wątpienie stanowi przejaw życia duchowego. A zatem poprzez sam akt zapytywania się o sprawy, które przekraczają nasze możliwości poznawcze, rośnie w nas świadomość samoistnienia jako egzystencji, która wykracza poza doraźny sposób bycia.

Tym bardziej za nieuprawnione uznaję wnioski wyciągane przez badaczy kina, którzy w filmach kwalifikowanych przez mnie jako postsekularne dopatrują się trwałych wartości i na drodze uproszczonego schematu interpretacyjnego konfrontują je z wartościami, które uległy dewaluacji[41]. Przykładowo w ten sposób zostały sformułowane sugestie, iż w Żywocie Jezusa Brunona Dumonta wertykalny ruch kamery sugeruje obecność transcendencji[42], a w Melancholii Larsa von Triera, wbrew konsekwentnie prowadzonemu aktowi dekonstrukcji, finalnie na

[39] A. Kyrlezhev, op.cit., s. 23.

[40] P.M. Socha, Przemiana. W stronę teorii duchowo-

ści, Kraków 2014, s. 53.

[41] Pełniejsze stanowisko polemiczne przestawiam w artykule: Postsekularne doświadczenie końca. Intymna apokalipsa $w$ filmach Koń turyński (2011)

\section{Oryginalność \\ filmowego \\ postsekularyzmu}


gruncie świata wartości zwycięża poczucie odpowiedzialności i troska o innych[43].

Tego typu działanie wydaje się zgodne z klasycznym modelem analizy i interpretacji, której ostatnią część powinny stanowić rozstrzygnięcia na poziomie proklamowanych sensów, a zatem wyraźne wskazanie na świat istniejących wartości, lecz jest nieadekwatne w stosunku do postmodernistycznej sztuki filmowej. Rewolucyjna siła europejskich filmów postsekularnych polega bowiem na tym, iż kwestię wartości (które mają swoje źródła w religijnych pytaniach) podejmują one w ramach spectrum, a nie zerojedynkowych rozstrzygnięć. Z jednej strony owego spectrum znajduje się fundamentalna dla rodzaju ludzkiego potrzeba dostrzegania w świecie trwałych wartości, na drugim zaś krańcu widnieje permanentny kryzys wartości wynikający z ich nierealności - obserwacja, iż przynależą one wyłącznie do tworzonych przez ludzi zmiennych dyskursów. Kryzys świata wartości odbiera im status uniwersalnych i trwałych pojęć, które można nałożyć na świat, w jakim żyjemy i - budując w ten sposób poziom niezmiennych znaczeń - przeciwstawić się jego bezsensowności i przygodności.

W ten sposób filmy postsekularne mogą pretendować do miana najbardziej znienawidzonych przez widzów, ponieważ zirytują zarówno wierzących, jak i ateistów. Dyskomfort, jaki staje się udziałem odbiorcy kina postsekularnego, wiąże się z zakotwiczoną w nas koniecznością hierarchizowania wartości, by następnie kierować się w życiu (społecznym i indywidualnym) tymi, które uznaliśmy za słuszne. W przypadku kina postsekularnego znane i ugruntowane przez nas systemy wartości po prostu nie działają. Filmy, o których tu mowa, dekonstruują każdy system wartości jako kolejną formę myślenia systemowego - co nie dziwi przy wskazaniu na ich postmodernistyczne korzenie, ale co może wzbudzić oburzenie i realny niepokój, ponieważ świat, w którym wartości nie tworzą nadrzędnego sensu, pozostanie na zawsze wyłącznie chaotyczny, chwilowy i nieprzewidywalny.

Nie znaczy to jednak, że w postsekularnym świecie czeka nas jedynie osunięcie się w pesymizm i bierność. Film Poza szatanem obfituje w sceny uzdrowień, modlitw i cudów, łącznie z tym najpotężniejszym aktem zmartwychwstania. Makrokosmiczna skala zdarzeń Melancholii ukazuje życie ludzkie w relacji do innych istnień i nieoczywiste, spektakularne piękno końca świata jako źródło przeżyć granicznych: estetyczno-filozoficzno-etycznych. Tytułowe to, co Ukryte, w filmie Hanekego wskazuje na wymiar, który jest niemal nieopisywalny, a jednak istniejący w sposób tak przejmujący, iż determinuje kształt fasadowych zdarzeń. W ten sposób kino postsekularne dowodzi, że nie jest jakąś poślednią formą, wydmuszką z nasyconego symboliką kina religijnego, lecz stanowi autonomiczny projekt, będący alternatywą dla religijnego dyskursu.

[43] M. Cauchi, The Death of God and the Genesis of Worldhood in von Trier's Melancholia, [w:] Immanent Frames..., s. 120-122. 
Postmodernistyczny sztafaż językowych narzędzi, takich jak ironia, intertekstualność czy dekonstrukcja schematów odbiorczych, umożliwiają oryginalne odpowiedzi na znane nam od zarania źródłowo religijne pytania, w pełni ujawniając zdolność sztuki do twórczych transformacji na poziomie sensów. Czyż to nie ironia najwyższej próby, wprost wymierzona w apokaliptyczne wizje duchowego spełnienia, gdy bohaterowie Konia turyńskiego w obliczu realizującego się właśnie końca świata $z$ konsternacją pochylają się nad surowym ziemniakiem? Życie jako autentyczna egzystencja oznacza ciągłe podejmowanie ryzyka bez nadziei znalezienia oparcia w jakiejś formie absolutu - i choć jest to zadanie być może niewdzięczne, to w nim właśnie przejawia się pełnia życia jako twórczości. Zaś dekonstrukcja znaczeń tradycyjnie przypisanych pojęciom nie tylko sprzyja dewaluacji wartości, lecz także (zwrotnie) pobudza kreatywność w obszarach dotychczas niepenetrowanych w kontekście duchowym. Wystarczy prześledzić, ile poczyniono dotychczas interpretacji religijnych obrazów jako symboli o soteriologicznym znaczeniu; kto zaś w tym kontekście pokazał potencjał surowego ziemniaka?

Bal M. Wędrujace pojęcia w naukach humanistycznych, przeł. M. Bucholc, Warszawa 2012

Barthes R., Śmierć autora, przeł. M.P. Markowski, „Teksty Drugie” 1999, nr 1/2, s. 250

Biblia Tysiąclecia, <https://biblia.deon.pl/rozdzial.php?id=324>, dostęp: 2.04 .2021

Britannica Encyclopedia of World Religions, red. W. Doniger, M. Frassetto, Chicago 2006

Caruana J., Cauchi M., What is postsecular cinema? An introduction, [w:] Immanent Frames: Postsecular Cinema between Malick and von Trier, red. J. Caruana, M. Cauchi, New York 2018, epub

Cooper S., The Soul of Film Theory, New York 2013

Deacy C., Ortiz G.W., Theology and Film: Challenging the Sacred/Secular Divide, Malden 2008, epub

Donnelly S., Inglis T., The media and the Catholic Church in Ireland: reporting clerical child sex abuse, „Journal of Contemporary Religion” 2010, nr 1 (nr 25), s. 1-19

Immanent Frames: Postsecular Cinema between Malick and von Trier, red. J. Caruana, M. Cauchi, New York 2018

Kendall T., No God but cinema: Bruno Dumont's Hadewijch, „Contemporary French and Francophone Studies" 2013, nr 4 (nr 17), s. 405-413

Kyrlezhev A., The postsecular age: Religion and culture today, „Religion, State and Society" 2008, nr 1 (nr 36), s. 21-31

Lyotard J-F., Nota o sensach przedrostka post-, [w:] J-F. Lyotard, Postmodernizm dla dzieci. Korespondencja 1982-1985, przeł. J. Migasiński, Warszawa 1998, s. 101-109.

Marczak M., Poetyka filmu religijnego, Kraków 2000

McLeod H., The Religious Crisis of the 1960s, New York 2007

Otto R., Świętość, przeł. B. Kupis, Warszawa 1999

Oxford Dictionary of Film Studies, red. A. Kuhn, G. Westwell, Oxford 2012

Post-secular Philosophy. Between Philosophy and Theology, red. Phillip Blond, New York 1998 
Religion in Contemporary European Cinema: the Postsecular Constellation, red. C. Bradatan, C. Ungureanu, London 2014

Roberts M.V., Hadewijch (mid 13th century), [w:] The Encyclopedia of Christian Civilization, red. G.T. Kurian, Malden 2011

Secularisms in a Postsecular Age? Religiosities and Subjectivities in Comparative Perspective, red. J. Mapril, R. Blanes, E. Giumbelli, Cham 2017

Socha P.M., Przemiana. W stronę teorii duchowości, Kraków 2014

The Concise Dictionary of World Religions, red. J. Bowker, New York 2000

The Post-Secular in Question: Religion in Contemporary Society, red. P.S. Gorski, D. Kyuman Kim, J. Torpey, New York 2012

The Routledge Handbook of Postsecularity, red. J. Beaumont, New York - London 2018

Ungureanu C., Final remarks what is the use of postsecularism?, [w:] Religion in Contemporary European Cinema: the Postsecular Constellation, red. C. Bradatan, C. Ungureanu, London 2014, s. 199-219

Walton S, Film and/as devotion: Bruno Dumont's Enworlded Cinema, „Australian Journal of French Studies" 2015, nr 2 (nr 52), s. 188-203

Weibler P., The re-enchantment of the world and the end of modern art, [w:] The New Visibility of Religion: Studies in Religion and Cultural Hermeneutics, red. M. Hoelzl, G. Ward, New York 2008, s. 117-127 